\title{
Biçimsel ve Biçimsel Olmayan Sosyal Ağların Sosyal Sermaye Edinimindeki Rolü: Kadın Yönetim Kurulu Üyeleri Üzerine Bir Araştırma ${ }^{1}$
}

\author{
The Role of Formal and Informal Social Networks in Social Capital \\ Acquisition: An Investigation on Women Board Directors \\ Hale ALAN \\ Türk Patent ve Marka Kurumu \\ 06330 Yenimahalle \\ Ankara, Türkiye \\ haletpe@gmail.com

\section{H. Cenk SÖZEN} \\ Başkent Üniversitesi \\ İktisadi İdari Bilimler Fakültesi \\ Ankara, Türkiye \\ csozen@baskent.edu.tr
}

\section{Özet}

Sosyal sermaye kuramı ve temelini sosyometri çalışmalarından aldığı kabul gören sosyal ağ yaklaşımına yoğun ilgi nedeniyle bu araştırmada sosyal ağ içinde kadın yöneticilerin sahip oldukları biçimsel ve biçimsel olmayan ağ bağlarına ve biçimsel olmayan gruplar içerisinde yer alma eğilimlerinin fazla olmasının sosyal sermaye edinimindeki rolü üzerine odaklanılmıştır. Biçimsel olmayan ağların sosyal sermaye edinimindeki önemi Borsa İstanbul A.Ş.'de aktif olarak işlem gören şirketlerin yönetim kurullarında görev yapan bağımsız kadın yönetim kurulu üyeleri üzerinde yapılan çalışmada ortaya çıkartılmıştır. Her kadın üyenin sahip olduğu ilişki, bağ ve temasları belirlenerek, UCINET 6.0 ve Microsoft Excel programı kullanılarak ağ ilişkileri matrisleri ve ağ haritaları oluşturulmuştur. Çalışma kapsamında ortaya çıkmış olan önerme kadın yönetim kurulu üyeleri üzerinde sınanmış olup, bu önerme ile kadın yöneticilerin kariyer gelişimlerindeki biçimsel olmayan ă̆ ilişkileri ve biçimsel olmayan gruplar içerisinde yer alma eğilimleri ile edindikleri sosyal sermayelerinin fazla olmasının beklendiği sonucu ortaya çıkmıştır.

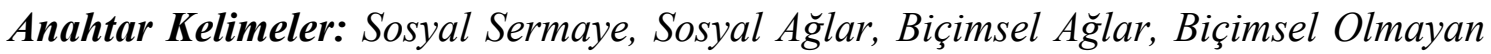
A ğlar, Kadın Yönetim Kurulu Üyeleri

\section{Abstract}

This research is focused on the role of individuals in social networking in the acquisition of formal and informal network connections and the tendency to take part in unstructured groups in social capital, as it has recently been highly interested in social capital theory and social networking approach, which is regarded as based on sociometry studies. The importance of the acquisition of social capital by informal networks has been realized on the independent women's board directors working on the boards of actively traded companies of Borsa Istanbul A.Ş. By defining the

\footnotetext{
${ }^{1} \mathrm{Bu}$ çalışma birinci yazarın "Kadınların Kariyer Gelişimlerinde Sosyal Sermaye Edinme Biçimleri: Bağımsız Kadın Yönetim Kurulu Üyeleri Üzerine Bir Araştırma” başlıklı doktora tezinden türetilmiştir.
} 
relationships, ties and contacts that each women board director have, UCINET 6.0 and the Microsoft Excel program have been used to create network relations matrices and network maps. It is expected that informal network relations will provide more benefits when formal and informal networks evaluate the importance of acquiring social capital. The research proposal put forward in this study has been tested on woman board directors and this suggests that woman managers are expected to have more unregulated network relations in their career development and tendency to take part in informal groups and social capital they get.

Keywords: Social Capital, Social Networks, Formal Networks, Informal Networks, Women Board Directors

\section{Giriş}

Sosyal sermaye kuramı farklı disiplinler ve farklı araştırmacılar tarafından çok sayıda tanıma sahiptir. Bu çalışmada sosyal sermayenin sosyal ağ ilişki ve bağlantıları bakımından ediniminde resmi ve sınırları açık olarak belirgin olan, üyeleri tanımlı ve çalışanlar tarafından resmi olarak tanınan biçimsel ağlar ile sosyal ilgi grupları, birlik ve dayanışma ilişkilerinden oluşan biçimsel olmayan sosyal ağ ilişkilerini ortaya çıkartmak hedeflenmiştir. Sosyal sermaye ve sosyal ağ kuramları kadınların üst düzey yönetim kadrolarına gelme sürecine kapsamlı bir bakış açısı kazandırmasına ragmen, sosyal sermaye ve sosyal ağ ilişkilerinin kadınların kariyer ilerlemeleri üzerindeki etkisi araştırmacılar tarafından ihmal edilmiş konular arasında yer almaktadır (Hawarden, 2010). Durbin'de (2011) biçimsel ve biçimsel olmayan ağlara üst düzey yönetici kadınların erişiminin erkeklerin yerleşik ağ ilişkileri nedeniyle kısıtlandığını belirtmiştir. Sosyal ağ özellikleri kadınların hiyerarşi olarak daha yüksek düzeylere ulaşmaları için önemlidir. Sosyal ağ ilişkilerinde cinsiyet farklılıklarını ortaya çıkaran çalışmaların (Durbin, 2011; Kanter, 1977; Hansen ve diğerleri, 2010) yanı sıra çok az çalışmada kadın ve erkek ağları arasında fark olmadığı ortaya çıkmış olup , bu çalışmalarda kadınların sosyal sermaye geliştirmelerinde sosyal ve profesyonel kulüp üyeliklerinden oluşan biçimsel olmayan ağ ilişkilerine ağırlık vermelerinin ve yeni bağlantı ve üyelik oluşturmaya daha fazla zaman harcamalarının etkili olduğu gözlenmiştir (Loscocco ve diğerleri, 2009: Cromie, 1992). Örgüt araştırmacılarının biçimsel olmayan ağlardan kadınların daha fazla faydalanmak istemelerinin önemini vurgulamaları bu ağların daha fazla etkili olduğunu göstermektedir (Burt, 1992). Bu çalışmada kadınların çalışma hayatında yükselmelerinde biçimsel ve biçimsel olmayan sosyal ağlarının, sosyal sermaye edinimlerindeki rolü üzerine ortaya konulmuş önermenin kadın yönetim kurulu üyelerinden oluşan araştırma evreni üzerinde sınaması yapılmıştır.

\section{Sosyal Sermaye Kuramı ve Sosyal Ağlar Tartışmaları}

Sosyal sermayenin kuramsal çerçevesini oluşturan kuramlar, sosyal ağlar temelinde gelişmiştir. Sosyal sermayenin önemli bir bileşeni olarak kabul edilen sosyal ağlar, sosyal sermayenin yaratılması ve geliştirilmesi için bir ön koşul niteliğindedir. Ağlara katılım ve yoğun bir sosyal ağ ilişkisinin var olması, sosyal sermayenin oluşması için gerekli bir koşul olmaktadır. Son yıllarda akademik araştırmacılar kadar farklı disiplinlerden birçok çalışmacının üzerinde yoğun olarak odaklandığı sosyal sermaye üzerine çok sayıda çalışma başlığı oluşturulmuştur. Sosyal sermayenin farklı tanımlamaları bulunmaktadır. Sosyal sermaye; toplumu oluşturan bireylerin, sosyal ilişki bağları ve etkileşimlerle resmi kurumlara ve sivil toplum kuruluşlarına üyelikleri 
aracılığıyla elde edinilen fayda ve üstünlükleri araştıran ve gelişimini sağlayan bir kavramdır. Bireylerin ilişki ağlarından edinerek sahip oldukları mevcut ve potansiyel kaynaklar toplamı sosyal sermaye olarak ifade edilmektedir (Nahapiet ve Ghoshal, 1998:243). Coleman (1988:104) sosyal sermayeyi, bireyler arasında oluşan ilişkilere ve ağlara odaklanarak tanımlarken, Fukuyama (2000:3) bireyler arasında koordinasyonu ve işbirliğine yönlendiren ve içten ilişkilerin baskın olduğu kalıplaşmış davranış kalıpları olarak tanımlamaktadır. Diğer bir tanıma göre sosyal sermaye, bireylerin ortak bir amaca ulaşmak için karşılıklı güven, paylaşılan değerler ve ilgiyle kurduğu ve koruduğu bağlar ile hareket etmesi olarak tanımlanabilir. Lin (2001) sosyal sermayeyi sosyal ağlarda yer alan ve aktörler tarafından erişilerek kullanılan kaynaklar seti olarak tanımlamıştır. Sosyal sermayenin bireylerden başka sosyal ilişkilerde yer alan kaynakları içermesi ve bu kaynakların erişimi ile kullanımının bireyler tarafından sağlanması olarak iki önemli unsurdan söz edilmekte olup, onun tanımında sosyal sermaye bir ă̆ araştırmacısı olmasından dolayı sosyal ağlarda insanlar arasındaki bağlantılara odaklanmaktadır (Lin, 2001: 24-25). Sosyal sermaye belirgin bir bağlam içindeki bireyin eylem ve faaliyetlerini kolaylaştıran etkileşimler, ilişkiler, bağlar, güven ilişkileri, değer ve norm sistemleri gibi farklı toplumsal alanları kapsayacak bir kavram haline gelmiştir (Anderson ve Jack, 2002:193). Örgüt açısından ise sosyal sermaye, sosyo-ekonomik ve kültürel ilişkiler sonucunda kazanılan kaynaklar olarak tanımlanabilmekte, sosyal ve kültürel ilişki kalıplarının tüm üretim aşamalarına uyum sağlayan ya da engelleyici etkileri olabilen unsurlar olarak incelenmektedir (Granovetter, 1985:481-510).

Sosyal sermaye kavramı ile birlikte sosyal ağ yaklaşımı da önem kazanmış, sosyal sermaye ve sosyal ağları birbirini tamamlayan unsurlar olarak gören çalışmalar olduğu gibi, sosyal sermayeyi sosyal ağlarda saklı olan ve sosyal ağlar sayesinde harekete geçirilen bir varlık olarak değerlendiren çalışmalar da mevcuttur (Inkpen ve Tsang, 2005). Sosyal sermaye kavramı ile birlikte insan ilişkilerinin örgütlere sağlayacağ muhtemel faydalar tartışılmaya başlanmış ve sosyal sermayenin ölçümü konusunda araştırmalar yapılmıştır. İlgili yazında, sosyal sermayenin, aktörlerin sosyal ağlara ya da diğer sosyal ilişki yapılanmalarına katılımıyla çeşitli faydalar yaratma yeteneğini desteklediği yönünde yoğun bir tartışma bulunmaktadır. Sosyal ağ analizi insanlar arasındaki bağlantıları ve bu bağlantıların özelliklerini görsel olarak resimleme yoludur. Wasserman ve Faust (1999) dört temel sosyal ağ kuramını kullanarak temel prensipleri tanımlamıştır. Bunlar; aktörlerin bağımsızlığı, ilişki ve bağlar, ağların bireysel aktörlere sağladıkları veya kısıtladıkları, sosyal yapı tarafından oluşan uzun süreli bağlar ve ağlardır.

Sosyal ağların temel bakış açısı ise, sosyal etkileşimlerin yapısı ve kompozisyonu ve bu etkileşimlerin değerli kaynaklara erişiminin ne şekilde artırıldığıdır (Burt, 1997; Ibarra, 1997). Bu bakımdan örgütün içinden ve dışından diğer insanların yararlı katkısının artması ağ ilişkilerinin artmasında uygulama ve değerli bilgilerin örgüte kazanımını sağlamaktadır (Lankau ve Scandura, 2002). Örgütsel alanda ele alındığında geniş sosyal ağlara sahip yöneticiler ve örgütler büyük bir rekabet avantajı elde edebilir. Granovetter'in (1985:502) zayıf bağlar kavramına göre iki ağ düzeneği arasında aracılık rolü yaparak köprü oluşturan aracılar ağlar arasında güçlü bağlarla ulaşılamayacak bilgi ve fikirleri ağ içine ulaştırır. Örgütlerin gelişim ve performansına çalışanlar arası bağlar, işbirliği ve uyumlu çalışmanın katkısı sosyal sermaye çalışmalarına hız kazandırmış ve birçok alanda çalışma yapılmasına neden olmuştur. Örgüt üyeleri yöneticilerin seçimi 
sonucu bir araya gelirler. Kurulacak sosyal bağların oluşturduğu şebekeler ve bunun getirdiği birliktelikten doğacak olan işbirliği örgütleri başarıya taşıyacak önemli bir ölçüt olarak önem kazanır.

Sosyal ağ ilişkileri sürdürülebilir rekabet avantajı kaynağı olarak farklı bağlamlarda değerlendirilir (Leung ve diğerleri, 2005). Wasserman ve Faust (1999) aktörlerin ilişki ve bağlar kurarken bağımsız karar vermelerini, ağların bireysel aktörlere sağladığı faydalar veya zararların sosyal yapı tarafından oluştuğunu ve uzun süreli bağlar ve ağların oluşum gereğini dikkate alarak sosyal ağ kuramının temel prensiplerini tanımlamıştır. Bireyler arasında ve bir sosyal ağ içinde çok çeşitli düzeylerde ve özellikte ağ ilişkileri ve ilişki bağları bulunur. Bağımsız kadın yönetim kurulu üyelerinin hangi nitelikteki ağ ilişkilerinin kendilerine fayda yaratacağı ve sosyal sermaye olarak tanımlanabileceğinin belirlenebilmesi için, öncelikle zayıf bağlar (Granovetter, 1983), güçlü bağlar (Bourdieu, 1983; Coleman, 1988) ve aracılığın (Burt, 1992) etkili olabileceği bağlamsal koşulların açıklanması gerekmektedir. Granovetter (1973), zayıf bağların gücünü, Burt (1980) ise ağ düzeneğindeki yapısal boşluklar kavramlarını açıklarken örgütlerin yerleşik ilişkilerinin avantajlarını göz önünde bulundurmuşlardır. Sosyal ağlar yapılarına göre geniş veya dar, sürece göre de güçlü veya zayıf olabilmektedirler ve ağlar, ulaşılabilecek yerden daha fazlasına ulaşmayı, fiziksel olarak orada bulunmadan orada olmayı sağladıkları için bir aktörün ağı ne kadar genişse etkileşimde bulunacağı aktör sayısı da o kadar fazla olacaktır (Rangan, 2000: 822-823). A $\breve{g}$ oluşturma faaliyetlerinin ilk amacı sosyal sermaye edinmektir. Ağ oluşturma profesyonel birliklere, daha belirgin olmaya neden olan yüksek düzeyli görevler aramaya, sosyal aktivitelere katılmaya, profesyonel iletişimler kurmayı kapsayan biçimsel ve biçimsel olmayan ilişkiler şeklinde gerçekleşmektedir (Forret ve Dougherty, 2004). Kadınların ailesel ve yaşamsal koşul ve sorumluluklarının ağırlığına değinen Wang'e (2009) göre bu durum kadınların ağ kurmak ve de erkek baskınlığındaki ağlara girmek için yeterince zaman bulamamalarının başlıca nedeni olmaktadır.

Araştırmacılar eşit olmayan sosyal ağların özellikle biçimsel ağlara erişememenin kadınların kariyer gelişimini engellediğini, sosyal ilişkilerden oluşan ağlara bireylerin yerleşik olduğunu ve rekabet avantajının ağlar aracılığıyla kazanıldığını vurgulamaktadır (Kanter, 1977; Brass, 1985; Barr, 1998; Hodigere ve Bilimoria, 2015). Ibarra (1993) bireysel ağlardaki cinsiyet farklılıklarına vurgu yapan ilk araştırmacı olarak kadınların biçimsel olmayan etkileşim ağlarını tanımlarken kuramsal ve görgül olarak kadın ve erkek sosyal ağ farklılıklarını açıklamıştır. Ona göre ağ farklılıkları araştırılırken öncelikle kadın ve erkeklerin ağ oluşturmak için kullandıkları stratejilerde özellikle örgütsel kısıtlar ve farklılıklara odaklanan nedenler belirlenmelidir (Ibarra, 1993).

\section{Biçimsel ve Biçimsel Olmayan Ağlar}

Sosyal ağların biçimsel ve biçimsel olmayan ağlar olarak ayrımı en yaygın ayrım olarak sosyal ağların hem örgüt içi hem de örgüt dişında geliştirilebildiğini ifade etmektedir (Bourdil ve Géraudel, 2016; Livesey ve Rotheroe, 2007). Coleman'a (2010) göre ise çalışma hayatında ağ oluşumları biçimsel, biçimsel olmayan ve kişisel olarak yapılanmaktadır ve çoğunlukla erkek üstünlüğündedir. Buna göre biçimsel olmayan ağlar kişiler arası ilişkileri temel alarak (Granovetter, 1973; Burt, 1992) en fazla çalışılan ağ türü olduğu söylenebilir. Biçimsel ağlar resmi ve sınırları açık olarak 
belirgin olup, üyeleri tanımlıdır ve çalışanlar tarafından resmi olarak tanınmaktadır (McGuire, 2000). Bir aktörün biçimsel ağları ticari amaçlı federasyonlar ve topluluklar ve toplumun önde gelen lider kuruluşlarıyla bağlantılarından oluşmaktadır (Livesey ve Rotheroe, 2007). Van Emmerik ve arkadaşlarına (2006) göre bir örgütte yılda birkaç kez yapılan sosyalleşme amaçlı iş toplantıları da biçimsel ağ ilişkilerine örnektir. Çünkü tarihleri belirgin, katılımcıları tanımlı ve toplantının amacı bellidir.

İnsanlar ağ ilişkilerinden bir beklentiye girmedikleri zaman ağ ilişkilerinin daha değerli olduğu düşünülür (Davidson ve Burke, 2000). Sosyal ilgi grupları, birlik ve dayanışma ilişkileri biçimsel olmayan sosyal ağ ilişkilerinin oluşmasını sağlamaktadır. $\mathrm{Bu}$ ağlar genellikle kendiliğinden veya belirli bir grup veya meslektaş ya da iş birlikleri tarafından geliştirilir (Lin, 2001). Biçimsel olmayan ağlar bireyin tercihinin sonucu olarak bireye sosyal faydalar sağladığı gibi işle ilgili faydalar elde edilmesini sağlar. Bireysel olarak aktörler hiyerarşi veya statü durumlarıyla ilişkili ağ bağlarına sahiplerse sosyal fayda ve uğraşları için biçimsel olmayan ağlar kurmaya yönelirler.

Kadınların biçimsel olmayan ağları ev ve çocuk bakım işleri nedeniyle boş vakit bulamamalarından dolayı azdır (Kanter, 1977; Hansen ve diğerleri, 2010). Biçimsel olmayan ağlar genellikle golf, futbol ve briç kulüplerine üyelik gibi fazla ve boş zaman gerektirerek kurulan bağlardan oluşur. Erkeklerin kadınlara göre daha fazla zamanının olması bu tarz üyeliklerinin fazla olmasına neden olmaktadır (Durbin, 2011). Kadınların biçimsel olmayan ağ bağlarına sahip olmaları kültüre bağlıdır ve batı kültürlerinde çok fazladır. Bu nedenle batıda kadınların yönetim kademelerinde sayısı biçimsel olmayan ağlara girme kolaylığından dolayı fazladır (Hansen ve diğerleri, 2010). Kanter (1977) kadınların biçimsel olmayan ağlara girmelerinin zorluğundan ve kadınların bu ağlara girerek kariyer ilerlemelerinin önünün açıldığından bahsetmektedir.

\section{Biçimsel ve Biçimsel Olmayan Sosyal Ağların Sosyal Sermaye Edinimindeki Rolünün Kadın Yönetim Kurulu Üyeleri Üzerinde Sınanması}

Ibarra (1992) kadın ve erkeklerin biçimsel olmayan ağlara erişim farklılıklarını açıklarken erkeklerin daha merkezi konumda ve diğer erkeklerle daha iyi ilişkiye sahip olduklarını vurgulamıştır. Kadınların ağ ilişkileri erkeklerin sosyal ağ ilişkilerinden farklı oluşum gösterdiği ve yazında kadınların sosyal sermayeye erişimlerinin eşit olmadığından ve devamlı ă dışında bırakılmalarından ve bu nedenle erkekler kadar sosyal ağ ilişkilerinden fayda sağlayamadıklarından sıkça söz edilmektedir (Barr, 1998; Bartol, 1978).

Kadınların sosyal ilişki ve bağlarının hem faydasını hem zararını gördüklerine dair Aaltio ve Huang'un (2007) Çin'de yaptıkları çalışma zengin sosyal ağlara sahip olan kariyer odaklı kadınların biçimsel olmayan sosyal ağlarından dolayı hem olumlu hem de olumsuz etkilere maruz kaldıklarını göstermiş ve ortaya çıkan bu sonuç kariyer ve cinsiyet ilişkisini çalışmanın kültürel bağlamda incelenmesinden dolayı hassas olan konular olduğunu göstermiştir. Kadınların iş yaşamında yükselmelerinde biçimsel olmayan bağlarının önemi göze çarpmaktadır. Kadınların biçimsel olmayan bağlar ile kariyer ilerlemelerini sağlamaları üzerine yapılmış çalışmalar bulunmaktadır (Van Emmerik ve diğerleri, 2006). Shortland'ın (2011) yaptığı çalışmada ise biçimsel olmayan ilişkilerden oluşan ağlara mensup olmaları kadınların kariyer ilerlemelerinde önemli olduğunu ortaya çıkarmıştır. 
Hangi tür sosyal sermaye biçimlerinin kadınların kariyer gelişimleri için daha faydalı ve etkili olduğu, çalışma hayatında öncelikle üst düzey görevlere gelmelerinin önünü açtığı ve kolaylaştırdığı üzerinde uzlaşılamamış konular arasındadır (Dulworth, 2008:47; Pini, Brown ve Ryan, 2004). Bununla birlikte araştırmacılar üst düzey görevlerdeki kadınların ağ ilişkilerini incelemiş, bilgi düzeylerine göre ağ konumlarını analiz etmiş ve az sayıda kadının ağ ilişkilerinden elde ettiği faydaları kullanarak cam tavan olarak tabir edilen görünmez engelleri aşabildiklerini ortaya çıkarmışlardır (Durbin, 2011). Kadın ağlarının güçlü ve baskın olan birey ve grupların oluşturduğu ağ ilişkilerinden mahrum kalması, yapısal olarak kısıtların çok olması ve yönetici kadınların sıkıntılı oldukları düşüncesi sosyal ağ ilişkilerinin etkililiğini azaltmaktadır (Heilman ve Haynes, 2005).

Kadınların erkeklerle aynı mesleği yapıyor olması onlarla aynı seviyede bilgi ve yeteneğe sahip olmaları gereğini ifade etmektedir (Timberlake, 2005). Bilimoria (2000) kadınların kendilerini uzun süre işlerine adayamadıkları ve bu nedenle erkeklerin gerisinde kaldıklarını vurgulamıştır. En üst düzeydeki pozisyonlarda kadın ve erkeklerin görevlendirilme dengesizliği kadınların ilişkisel ağ kurma tercihlerine bağlı olmaktadır. Kadın sosyal ağları doğru zamanda, doğru insanda, doğru iletişim yolunun oluşmasıyla sağlanmaktadır (Dulworth, 2008:47). Çok farklı düzey ve türde sosyal sermaye ve bağlı

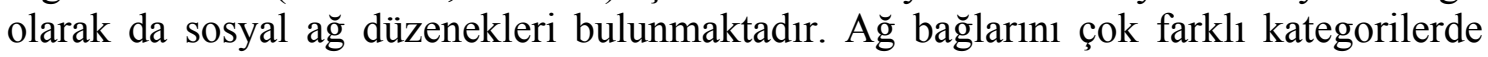
incelemek mümkündür. Burada önemli olan ilişkilerin karşılıklı olması ve her iki tarafa bağlı olarak nitelik kazanmasıdır. Bireylerin sosyal ağ kurma nedenleri farklılık göstermemektedir. Biçimsel olmayan ağ ilişkileri tamamen bireylerin kendi seçimleri sonucunda oluşmaktadır.

Linehan ve Scullion (2008) çalışmalarında erkeklerin iş dışında da bir arada zaman geçirmek için firsatlar yaratırken üst düzeylerde görev yapan kadınların ise kadın gruplaşması kurmak için tereddüt ettikleri ve bunun nedeni olarak da kadınların kendilerini diğer kadınlardan soyutlamak istemeleri olduğu belirtilmiştir. Toplumsal güç ve kültürle ilişkilendirilen sadece kadın ağlarının, eski erkek ağları ve erkeklerin biçimsel olmayan ağlarının engel olması nedeniyle oluşmalarının zor olduğu, buna rağmen erkeklerin hemcins ağlarına karşı bir tutum olarak kabul edildiği söylenebilir. Kadınlar toplumsal güç ve kültür bağlamında olumsuz kalıp yargılar nedeniyle toplumda daha düşük statüye sahip olmakta ve çalışma hayatında erkeklerin gerisinde bırakılmaktadır (Fletcher ve diğerleri, 2007; Perriton, 2006).

Önemli ağlara katılım ve ağlardan fayda sağlamak için devamlı arka planda kalan kadınlar bu eksiklerini erkek meslektaşlarıyla bağlar kurarak tamamlamaya çalışmaktadır (Burke ve diğerleri, 1995; Barr, 1998). Bu amaçla öncelikle biçimsel ağlara girmek için başarılı ve yetenekli erkeklerin biçimsel olmayan ağlarına girerek avantaj kazanabilirler. Erkeklerin yerleşik oldukları sosyal ağları onların zirvedeki konumlarının kalıcı olmasını sağlamaktadır (Barr, 1998). Kalıcı olmak demek sosyal ağ düzeneğindeki aktörlerin değişmemesi ve ağ ilişkilerinin çok dinamik olmaması ile ortaya çıkan biçimsel olmayan ağ bağlantıları ve profesyonelleşmiş sosyal sınıfın sağladığı ayrıcalıklı ağ üyeliğidir (old boy network). Kadınların kariyer gelişimleri için mücadeleleri henüz işe giriş aşamasında kendini göstermektedir (Sheridan, 2002). İşe seçim aşamasında ayrımcılık oluşmakta, açılan pozisyonlarda yaratılan firsatlardan birbirlerini eski erkek ağları (old boy's network) ile haberdar eden erkekler bir araya gelmekte ve erkek meslektaşlarıyla eşit düzeyde niteliklere sahip kadınlar henüz işe girme aşamasında daha alt düzeylere itilmektedir (Ragins ve Sundstrom, 1989). 
Bourdil ve Géraudel'a (2016) göre kadınların biçimsel ağları profesyonel iş kadınları ile kurdukları ağlar olarak incelenmiştir. Kadınlar erkek baskınlığındaki iş ağlarına girmede zorluk yaşamaktadır (Pini, Brown ve Ryan, 2004). Bu yüzden kadınlar yönetsel düzeylere ulaşmak için sayısız olumsuzluğa maruz kalmakta ve kariyer gelişimleri çok yavaş olmaktadır. A $\breve{g}$ ilişkilerine odaklanan çalışmalarda biçimsel olmayan ağ ilişkileri araştırılmaktadır. Buna göre cinsiyet farklılığı biçimsel olmayan ağlara üyelikler, biçimsel olmayan ağ ilişkilerini iş nedeniyle kullanma oranı araştırılmaktadır (Van Emmerik ve diğerleri, 2006). Van Emmerik ve arkadaşlarına (2006) göre kadınlar için biçimsel ve biçimsel olmayan ağlara üyeliğin farklı sonuçları bulunmaktadır (McGuire, 2000). Biçimsel olmayan bağlarda örgütün herhangi bir sorumluluğu bulunmamaktadır (McGuire, 2000). Hem biçimsel hem de biçimsel olmayan ağ ilişkilerinin kariyer gelişimiyle ilişkisinin belirlenebileceği vurgulanmaktadır (Van Emmerik ve diğerleri, 2006). Van Emmerik ve arkadaşlarına (2006) göre kadınların biçimsel ve biçimsel olmayan bağlarının kariyer beklentileriyle çok fazla ilgisi bulunmaktadır. Biçimsel olmayan ağlara girmenin herhangi bir yaptırımı ve mecburiyeti olmadığından söz eden çalışmalarda (Van Emmerik ve diğerleri, 2006; McGuire, 2000) bu bağların çabuk sosyalleşme, meslektaşlarıyla kaynaşma ve iyi zaman geçirme yani eğlence amacıyla kurulduğu söylenebilir. Kadınların erkeklere göre tam zamanlı olarak da biçimsel olmayan ağlara girdikleri belirtilmektedir. Buna göre Cannings ve Montmarquette'nin (1991) kadın müdürler üzerinde yaptıkları çalışmada biçimsel olmayan ağların kadınların kariyer gelişimi üzerinde olumlu etkiye sahip olduğu belirtilmiştir.

Yönetsel düzeydeki kadınların örgüt içi ve dışında birçok ilişki ağları bulunmaktadır ve hem biçimsel hem de biçimsel olmayan ağ ilişkilerine sahip oldukları görülmektedir (Burke ve diğerleri,1995). Biçimsel ağlara sahip üyeler birbirlerini daha yakından tanımakta ve güçlü bağlara sahip olmaktadırlar. Biçimsel ağlar üyelerine daha fazla bilgi erişimi, mentörlük, politik destek sağlaması beklendiğinden kariyer gelişimiyle olumlu yönde ilişkilidir (Friedman ve diğerleri, 1998). Van Emmerik ve arkadaşları (2006) biçimsel ağ üyeliklerini belirlemek için ağ düzeneğindeki biçimsel oluşumları hesaplamışlardır. Aynı çalışmada biçimsel olmayan ă̆ üyeliklerini hesaplamak için dört maddelik sınıflama geliştirmişlerdir. Bunlar; meslektaşlarıyla, şef ya da koordinatörleriyle, koçlarıyla ve son olarak da mentör, sponsor gibi ilişkilerinin sayısı belirlenmiştir. Erkeklerin davranışları çoğunlukla biçimsel olmayan ağ ilişkilerini, uzun sürede oluşan erkek ağlarını, golf dersleri, av faaliyetleri, klüp etkinlikleri ve spor faaliyetlerini kapsamaktadır (Waring, 1988). Kadınların biçimsel ağlara erişimlerinin sınırlı olması onların yönetim kurulu üyesi olmalarını engellemektedir (Burke, 2000). Yapısal boşluk olarak ağın zayıf olması sosyal sermaye düzeyinin de zayıf olması demektir (Burt, 1997, 1998). Terfi ve kariyer gelişimi biçimsel olmayan ağlarla ilişkiye sahip olmakla yakından ilgili olmaktadır ve bireyin biçimsel olmayan ağ ilişkilerinin çok olması daha fazla fayda sağlamasına neden olmaktadır (Podolny ve Baron, 1997; Burt, 1998, 2005).

Her iki bağ oluşumunun kariyer gelişiminde etkisinin fazla olması, özellikle biçimsel olmayan bağların heterojen grupların ve bilgi kaynakları sayesinde kariyer fırsatı sunmaktadır. Powell (1993) kadınların üst düzey yönetim kademelerine ilerleyememelerinin nedeni olarak erkekler kadar biçimsel olmayan ağlara tam olarak sahip olmamalarını göstermektedir. Shortland'a (2011) göre biçimsel olmayan ağlara dâhil olmanın çok değerli olduğu bilinmesine rağmen biçimsel ağlara girmek bir kadın 
için kariyerinde ilerlemeyi kolaylaştırmaktadır. Coleman, (2010) ağ düzeneklerinin büyüklük ve biçimsellik düzeyine göre değişim gösterdiği vurgulanmıştır. Buna göre küçük ağların gönüllü faaliyetlerle kurulduğu, geniş ağların ise biçimsellik düzeyinin fazla olduğu belirgindir. Fletcher ve diğerlerine (2007) göre kadınların erkeklerden oluşan biçimsel olmayan ağ düzeneklerine girmeleri erkeksi olarak nitelenen davranış kalıplarını benimsemeleri ile gerçekleşmektedir.

Erkeklerin sahip oldukları özellikle ekonomik fayda sağlayan ağ bağlarının çeşitli sosyal kurumlarla yaptıkları çoğunlukla gönüllü ve özel hayatlarına ait ağ üyelikleri olduğu belirtilmektedir (Davidsson ve Honig, 2003). Ibarra (1992, 1997) çalışmalarında kadınların biçimsel olmayan ağ üyeliklerinin öneminin farkında olmadıklarını ve iş yaşamında da bu nedenle geri planda kaldıklarını vurgulamaktadır. Ibarra'da (1992) kadınların biçimsel olmayan ağ üyeliklerini sadece arkadaşlık ve sosyal destek olarak gördüklerini ve biçimsel olmayan ağlardan kariyer ilerlemeleri için fayda elde edemediklerini ortaya çıkarmıştır. Brass (1985) çalışmasında da kadınların biçimsel olmayan ağ ilişkilerinin az sayıda olmasının güç kazanımı ve kariyer ilerlemelerinin geri kalmasına neden olduğunu belirtmiştir.

Kadınların çalışma hayatında yükselmelerinde biçimsel olmayan bağlarının önemi göze çarpmaktadır (Livesey ve Rotheroe, 2007). Örgütlerde k1demli ve profesyonel erkeklerden oluşan baskın gruplaşmaya karşı üst düzey yönetici kadınların bu yapısal engellerin üstesinden gelmeleri biçimsel olmayan ağlara dâhil olmalarıyla gerçekleşecektir (Rindfleish ve Sheridan, 2003). Shortland (2011) çalışmasında biçimsel olmayan ilişkilerden oluşan ağlara mensup olmalarının kadınların kariyer ilerlemelerinde önemli olduğunu ortaya çıkarmıştır. Brass'da (1995:330) kadınlar az sayıda biçimsel olmayan ağ düzeneği kurmalarının sonucunda kendi grupları dışındaki diğer bireylerle daha az iletişim kurduklarını ortaya çıkarmıştır. Bilinen ve bilgi akışı fazla olan bir ağa giren kadınların kariyer ilerlemeleri daha hızlı olmaktadır (Shortland, (2011). Burt (1998) bireylerin nerede en rahat iseler orada daha iyi performansa sahip olacaklarını vurgulamıştır. Kadınların meşruiyet sağlama sorununu ve kurulmuş ağlara girme engellerini biçimsel ağlar sayesinde aşabilecekleri düşüncesiyle Burt'e (1998) göre erkekler için biçimsel olmayan ağlar daha rahat iken kadınlar için biçimsel ağların daha rahat olması gereğini vurgulamıştır. Biçimsel ağlar örgüt politikası, yazılı iş tanımları gibi içerikleri kapsaması nedeniyle kadınların kariyer gelişimlerine yardımcı olacağı düşünülmektedir. Fakat kültürel kısıtlar ve cinsiyet kalıp yargılarının kadınların kariyer gelişimlerindeki olumsuz etkileri unutulmamalıdır. Bu bağlamda, biçimsel ağlar daha az çalışılmış olması ve tanımlanmış kural ve politikaları baz alması nedeniyle kadınların iş yaşamlarında başarıyı yakalamalarının çözümü olarak görülebilir. Hâlbuki cinsiyet ayrımı ile baş etmek isteyen tüm kadınların biçimsel olmayan ağların önemini anlaması daha önemli olduğu (Maxwell ve Broadbridge, 2014) ve karar verme sürecinde daha baskın olan görevlerde biçimsel olmayan ağlara girmenin olumlu sonuçlar vereceğini vurgulamıştır (Powell, 2000).

Kadınların katılmış oldukları biçimsel olmayan ağ ilişkilerine dair sadece iki çalışmada cinsiyet farklılıkları olmadığı ortaya çıkartılmış ve bu çalışmalarda kadınların sosyal sermaye ediniminde sosyal ve profesyonel kulüp üyelikleri gibi biçimsel olmayan ağ ilişkilerine ağırlık vermelerinin ve yeni bağlantı ve üyelik oluşturmaya daha fazla zaman ayırmalarının etkili olduğu belirtilmiştir (Loscocco ve diğerleri, 2009: Cromie, 1992). Biçimsel ağlar kadınların üst düzey görevlere gelmelerinin önünü açmak için oluşturulmaktadır. Fakat kadınların kariyerlerinde yükselme veya 
ilerlemeleri erkeklerin hâkimiyetinde olan iş yaşamında fayda sağlayan biçimsel ağlar kurmalarına veya bu ağlara girmelerine engel olmaktadır. Kadınların herhangi bir müdahale ve destek olmadan biçimsel ağ ilişkileri kuramayacakları gerçeğinden yola çıkılarak oluşturulan biçimsel ağ ilişkileri kadın ve erkek ağ ilişkileri ve sosyal sermayelerinin farklı olduğunun kanıtı niteliğindedir.

Kadınların yukarıda anlatılan zorunluluklar ve karşılaştıkları engeller nedeniyle erkeklerin baskınlığında olan biçimsel iş ağlarına girememeleri biçimsel ağların sağladığı kariyer avantajlarına ulaşamamalarına neden olmaktadır (Coleman, 2010). Biçimsel olmayan ağlara girmeyi başarabilen kadınların çalışma yaşamında yükselmelerinde ve yönetim kurulu üyeliği gibi zor olan üst düzey görevlere seçilmelerinde sahip oldukları ve olmaya çalıştıkları ağ ilişkilerinin biçimsel ve biçimsel olmayan ilişki sınıflandırması altında incelenmesi yapılabilir. Kariyer gelişimini başarmak için kadınların sahip oldukları bağlardan en yüksek faydayı sağlama yoluna gitmeleri ve ă̆ oluşumlarında yararlı strateji uygulamaları doğrultusunda ne kadar fazla sayıda biçimsel olmayan bağ, ilişki ve temas geliştirilirse o kadar iş ve kariyer odaklı faydaya sahip olunacağı değerlendirilmektedir. Buna göre bu çalışmada öne sürülen önerme şu şekildedir;

Önerme: Kadın yöneticilerin üst düzey yönetim kadrolarına gelmelerinde sosyal ağlarında çok fazla biçimsel olmayan bağ, ilişki ve temaslara sahip olmaları beklenir.

\section{Yöntem}

\subsection{Araştırmanın Amacı ve Önemi}

$\mathrm{Bu}$ çalışma hem biçimsel ve biçimsel olmayan ağların sosyal sermaye edinimindeki önemine açıklık getirmeyi hem de biçimsel olmayan ağ ilişkilerinin daha fazla fayda sağladığını ortaya çıkarmayı amaçlamaktadır. $\mathrm{Bu}$ amaçla çalışma kapsamında kuramsal olarak öne sürülen önerme kadın yöneticiler üzerinde sınanmış olup, ülkemizde yönetim kurulu üyeliği gibi üst düzey görevlere gelmiş kadınların bu görevlere gelmelerinin önünü açan sosyal sermaye ve sosyal ağ ilişkilerini belirlemeye yönelik bir araştırma olarak yazında özgün ve eşsiz bir öneme sahip olacağ 1 düşünülmektedir. Kuramsal olarak taşıdığ yönetim kurulu üyelerinin sosyal ăg ilişkilerini inceleyerek sosyal ağ ilişkilerinin bireyin sosyal sermayesi hakkında ne kadar önemli bulgular ortaya çıkarttığını göstermek çalışmanın diğer bir amacıdır. Bu çalışmada genel amaç hem bireysel hem de örgütsel sonuçları etkileyen ve şimdiye kadar araştırılması ihmal edilmiş olan kadın yönetim kurulu üyelerinin (bağımsız üyeler) ilişki ve bağlantılarını sosyal ağ analizi yöntemini kullanarak biçimsel ve biçimsel olmayan sosyal ağ ilişkilerini incelemektir.

\subsection{Araştırmanın Kapsamı ve Evreni}

$\mathrm{Bu}$ çalışma ile Borsa İstanbul A.Ş'de işlem gören örgütlerin yönetim kurullarındaki bağımsız kadın yönetim kurulu üyeleri araştırılmıştır. Toplamda 588 örgüt incelenmiş ve 70 bağımsız kadın yönetim kurulu üyesinin ağ ilişkileri ve sosyal

sermaye düzeyleri araştırılmıştır. Sosyal ağ analizi için ağırlıklandırılmış matris yöntemi kullanılmıştır. Bağımsız kadın yönetim kurulu üyelerinin ilişkileri ikincil veri kaynaklarından araştırılmıştır. Arşiv verileri, özgeçmişler, gazete haberleri, kişilere ait web siteleri, kişisel bilgileri, mezun oldukları okullar, şirket ve çalışılan yerler, aile bağları, arkadaşları, gönüllü yapılan aktiviteleri araştırılmıştır. Ağ analizi için UCINET 6.0 versiyonu (Borgatti vd., 2002) kullanılmıştır. Analizlerde kullanılan bağımsız kadın 
yönetim kurulu üye veriler, BIST (www.borsaistanbul.com) ve Kamuyu Aydınlatma Platformu'na ait (www.kap.gov.tr) internet sitesi veri tabanlarından sağlanmıştır. Bağımsız kadın üyelerin kimlikleri gizlilik nedeniyle saklı tutulması amacıyla kodlama usulü kullanılmıştır. Üyeler X1,X2,X3,X4 ....X70 şeklinde kodlanmıştır. Bir ağ düzeneğinin yoğunluğu, düğümler arasında bilginin yayılma hızı, aktörlerin sosyal sermaye ve/veya sosyal kısıtlama düzeylerine ilişkin bilgi verebilir. Yoğunluk değerinin yüksek olması, aktörlerin birbirlerine güçlü bağlı olduklarını dolayısı ile birbirinden soyut olmadıklarını gösterir (Degenne ve Forse, 1999:46).

\subsection{Araştırmanın Yöntemi ve Ölçüm Aracı}

$\mathrm{Bu}$ çalışmada sosyal sermaye kullanımını belirlemeyi gerektiren yüzeysel bilgileri elde etmek için ilişkisel bilgileri elde etmek ve analiz edebilmek amaciyla sosyal ağ analizi yöntemi kullanılmıştır. Ağ ilişkilerinin davranışsal ve yapısal durumlarını bir araya getirmeyi sosyal ağ analizi sağlar. Sosyal ağ analizi kadın yöneticilerin ilişki ve bağlarını analiz etmek için kullanılabilecek hem bir bakış açısı hem de bir yöntem olarak bu çalışmada faydalanılmış bir kuramdır. Geniş kapsam ve imkânlarıyla kadınların bağlarındaki hemcinsleriyle olan (homofili) ilişki derecesini, çok yönlü ilişkilerini, ağın kapalılığı ve bağların yakınlık derecesini sosyal ağ analizi ile belirlemek mümkündür (Cabrera ve Thomas-Hunt, 2007). A $\breve{g}$ düzeneğindeki dağılımlardan ise, köprüler, merkezilik, yoğunluk, yapısal boşluklar ve bağların gücü belirler.

$\mathrm{Bu}$ çalışmada sosyal ağ analizi yaklaşımı ile bağımsız kadın yönetim kurulu üyelerinin sosyal sermaye ve sosyal ağ ilişkilerinin ortaya çıkartılması amaçlanmıştır. Son yıllarda uluslararası alanda oldukça ilgi çekmeye başlayan sosyal ağ analizi yöntemi kapsamlı bir şekilde kullanılmıştır. Sosyal, örgütsel ve ekonomik hayati şekillendiren gizli dinamikleri ve bilgi akışını (Sözen ve Sağsan, 2009: 67) ortaya çıkarmak için kullanılan ve geleneksel analiz yöntemlerinden farklı bir yöntem (Sözen, 2012:1-2) olan sosyal ağ analizi, zayıf veya kuvvetli bağların bulunduğu sosyal hayatta bağların gücünün ve işlevinin belirlenmesi için kuvvetli bir araçtır (Granovetter, 1983:229). Sosyal ağ araştırmacıları, analiz verisi olarak bağları ve ilişkileri kullanmaktadırlar (Seibert ve diğerleri, 2001:220). A $\breve{g}$ içinde verilerin toplandığı ve odaktaki kişi "ego", bağlı olduğu kişiler de "arkadaşlar" (alters) olarak adlandırılmaktadır (Knoke ve Kuklinski,1982). Araştırmanın ilk aşamasını ikincil kaynaklardan veri toplama ile ilgili faaliyetler oluşturmaktadır. Toplanan verilere göre sektörler temel değişkenler çerçevesinde sınıflanmış ve araştırma kapsamına alınan üyeler belirlenmiştir.

\section{4. Veri Toplama, Verilerin Girişi, Ağ Verilerinin Sınıflanması ve Önermenin Sinanması}

Bu çalışmada bağımsız kadın kurul üyelerinin sahip oldukları kişisel ilişkilerin yönetim kurulları için kazanılmış en geçerli ilişki biçimi olacağı varsayımından hareket edilerek, kadın bağımsız yönetim kurulu üyelerinin ilişkileri ikincil veri kaynaklarından araştırılmıştır. Araştırma kapsamında kullanılan araştırma yöntemi için ikincil kaynaklardan veri toplanması birçok farklı kaynağın aynı anda kullanılmasını gerekli kıldığından dolayı sentezlenmiş bir içerik sunmakta ve diğer yöntemlere nazaran okunması, analiz edilmesi ve bulguların ortaya konması aşamalarında zaman ve maliyet tasarrufu sağlamaktadır. Araştırma kapsamına alınan her bağımsız kadın yönetim kurulu üyesinin ülkede isim yapmış ve köklü firmaların kurullarında görev yaptıkları düşünüldüğünde, bilinirliklerinin fazla olacağı ve birçok bilgi veya habere ikincil veri 
kaynakları sayesinde ulaşılabileceği değerlendirilmektedir. Kaynaklardan ikincil veri toplanması bireyin tanınırlığının çok fazla olmasına bağlı olarak kolaylaşmaktadır (Abrahamson ve Fombrun, 1994). Burada araştırılan konu, kadın bağımsız yönetim kurulu üyelerinin hem kendi ağları (ego-centric network) hem de diğer aktörlerle aralarındaki ağ ilişkileri (whole network) olduğu için, analiz birimi bireydir. Önermenin sınanması amaciyla oluşturulmuş biçimsel ve biçimsel olmayan ağ ilişkileri matrisinin derece merkezilik değerleri ve ortalamaları (UCINET-Network $>$ Centrality $>$ Degree centrality) hesaplanmıştır.

Ağ ilişkilerinin belirlenmesi için her kadın üyenin diğer kurullarla sahip oldukları ilişkiler ve üyesi olduğu örgüt adına kurdukları bağlar araştırılmıştır. Yönetim kurulu üzerine yapılan çalışmalarda çoğunlukla arşiv verisi kullanılmaktadır. Arşiv verisi incelemek ikincil veri analizi yapmayı gerekli kılmaktadır. Yönetim kurulunda kadın üyelerin sosyal sermayelerini ve sosyal sermaye kullanım düzeylerini belirlemede bireylerin günlük hayattaki sosyal eylemlerini üretmelerini ve gerçekleştirmelerini sağlayan rutinleri, alışkanlıkları anlamayı ve tanımlamayı mümkün kılan ikincil verilerin faydalı olacağı düşünülmektedir. Bağımsız kadın yönetim kurulu üyelerinin sosyal sermaye ve sosyal ağ bağları ile ilgili bilginin güvenilirliğini artırmak amaciyla kadın yönetim kurulu üyeleriyle ilgili özgeçmişler, Borsa İstanbul A.Ş. yayınları, şirket çalışma raporları ve gazete haberleri, şirket internet siteleri, üyesi oldukları dernek ve kulüp bilgileri derlenerek incelenmiştir. Matris oluşturulurken Excel tablo editörü kullanılmıştır. UCINET tablo editörü Excel tablolarından veri alabilir ve gönderebilir özelliktedir (Hanneman ve Riddle, 2005). Veri girişleri Excel tablolara eş zamanlı girilmiştir. Kadın üyelerin ilişki ve bağ verileri sınıflama kıstaslarına uygun olarak ve ağırlıklandırılmış matris oluşturulacak şekilde toplanmıştır. Veri toplama sürecinde karşılaşılan yanıltıcı olacağı düşünülen nitelikteki varsayıma dayalı bilgiler, ilişkilerin belirlenmesinde değerlendirmeye alınmamıştır. $\mathrm{Bu}$ çalışmada gerçekleştirilen veri toplama aşaması sonucunda elde edilen ağ ilişkisi bilgilerinin işlenmesinde matris yönteminin kullanılmıştır. Sosyal ağ yapısı analizlerine dair araştırmalarda en kapsamlı ve en fazla kullanılan matris yöntemi sayesinde bireyler, gruplar, topluluklar ve örgütler arasında bulunan ilişkilerin veri girişi ve analizi yapılabilmektedir. Programa veri girişinde bir matris üzerinde aktörler arasında ilişkinin var olması durumunda 1, ilişki olmaması durumunda 0 değerinin verilerek ağ düzeneğinin ortaya çıkarılmaktadır (Hanneman, 2001).

İlişki biçimlerine dair tanımlamaların ağ analizi programı aracılığıyla yapılmış olmasına rağmen bu çalışmada öne sürülen önermenin sınanması için elde edilen değişik nitelikteki çok sayıdaki verinin sınıflandırılmasında yazından derlenerek oluşturulmuş başta Putnam (1995), Narayan (1999) ve Woolcock ve Narayan'da (2000) yapısal sosyal sermaye değişkenleri olmak üzere van Emmerik ve diğerlerinin (2006) çalışmalarında kullandıkları ağ ilişkisi sınıflandırması ve Bourdil ve Géraudel'un (2016) biçimsel ve biçimsel olmayan ağ ilişkileri sınıflandırmasına ait değişkenler kullanılmıştır. Çalışmada bulunan her ilişki ve temas için 0-1 arasında değerler bahse konu programda tablolara işlenmiştir. Van Emmerik ve arkadaşlarının (2006) çalışmalarında kullandıkları ağ ilişkisi sınıflandırması ve Bourdil ve Géraudel'un (2016) biçimsel ve biçimsel olmayan ağ ilişkileri sınıflandırmasına ait değişkenler kullanılmıştır. Çalışmanın önermesi kapsamında araştırmaya yer alan bağımsız kadın yönetim kurulu üyelerinin biçimsel ve biçimsel olmayan ağ ilişkileri sınıflandırma kriterleri ise Tablo 1'de sunulmuştur. 
Tablo 1. Kadınların A $\breve{g}$ İlişkilerinin Biçimsel ve Biçimsel Olmayan Şeklinde Siniflandirılmasi

\begin{tabular}{|c|c|}
\hline Biçimsel A $\breve{g}$ İlişkileri & Biçimsel Olmayan Ağ İlişkileri \\
\hline $\begin{array}{ll}\text { - } & \text { Sosyal Olmayan (resmi) İlgi } \\
\text { - } & \text { Iruplar Birlikleri Sonucu Oluşmuş İş } \\
& \text { Ağları } \\
\text { - } & \text { Ticari Amaçlı Federasyonlar } \\
\text { - } & \text { Ticari Amaçlı Topluluklar } \\
\text { - } & \text { Profesyonel Kulüp Üyelikleri } \\
\text { - } & \text { Sanayi ve Ticaret Odası Üyelikleri }\end{array}$ & $\begin{array}{l}\text { - } \quad \text { Sosyal İlgi Grupları } \\
\text { - } \quad \text { Birlik ve Dayanışma Toplulukları } \\
\text { - } \quad \text { Kar Amacı Gütmeyen Sivil Toplum } \\
\text { Kuruluşları ile ilişkileri (Dernek, Vakıf } \\
\text { vb.) } \\
\text { - Kendiliğinden Oluşmuş Topluluklar, } \\
\text { - } \quad \text { Sruplaşmalar } \\
\text { Spor Kulübü Üyelikleri }\end{array}$ \\
\hline
\end{tabular}

Tablo 1'e göre kadınların ağ bağları, ağ ilişkileri ağırlıklandırma ölçütlerinde gösterilen zayıf ve güçlü bağların kapsamında biçimsel ve biçimsel olmayan bağlar olarak ayrımı yapılabilmektedir. Araştırmanın önermesinde biçimsel ve biçimsel olmayan ağ ilişkileri arasındaki en belirgin farkın biçimsel ağ ilişkilerinin iş ve ticari amaçlı olması ve resmi bir oluşum olarak ortaya çıkması, biçimsel olmayan ağ oluşumlarının ise tamamen gayri resmi şartlar altında oluşum göstermesidir.

\section{Araştırmanın Bulguları}

Araştırmanın önermesi sınanmadan önce ağ düzeneğinin temel tanımlayıc1 analizleri yapılmıştır. Buna göre sosyal ağ düzeneğinin ilişki yoğunluğu testi ile kitlede bulunan bağımsız kadın üyelerin aralarındaki ilişkilerin yoğunluğu tespit edilmiştir. Araştırma kapsamındaki bağımsız kadın yönetim kurulu üyelerinden \%3,5'i 25-29 yaş grubu arasında, \%3,5'i 30-39 yaş grubu arasında, \%10,5'i 40-49 yaş grubu arasında, $\% 29,4$ 'ü 50-59 yaş grubu arasında ve \%2,1'i ise 60 yaş üzeridir. Araştırmada, bağımsız kadın yönetim kurulu üyelerinin \%51'i 50-59 yaş aralığında olduğu görülmüştür. Bu sonuç, bağımsız kadın yönetim kurulu üyelerinin en aktif yönetim kademelerinde görev almalarındaki yaş yoğunluğu bulgularını desteklemekle birlikte yönetim kurulu üyeliği görevinin önem ve ayrıcalığı tecrübe ve yaşla birlikte artmaktadır. Çalışma kapsamındaki kadın yönetim kurulu üyelerinin eğitim düzeyi yüksektir. Eğitim önemli bir sosyal sermaye niteliğidir. Bağımsız kadın yönetim kurulu üyelerinden 3'ü üniversite mezunudur. 60 kadın üye yüksek lisans düzeyinde eğitime sahiptir. 7 kadın üye doktora düzeyinde akademik unvana sahiptir. Kadınların 61'i evli, 6'sı bekâr, 3'ü boşanmıştır. Araştırma yapılan kadın üyelerin 52'sinin çocuğu vardır. 18 kadın üyenin çocuğu yoktur. Çocuğu olanların üyelerin ise 12'sinin tek çocuğu, 30'unun iki çocuğu, 10 'unun üç çocuğu bulunmaktadır. Kadın üyelerin yaş ortalamalarının yüksek olmasına bağlı olarak çocuklarının yaşlarının en küçügü 12 yaşında olduğu görülmektedir. Kadın üyelerin iş tecrübelerine bakıldığında en az 3 yıl en fazla 45 yıl tecrübeye sahip oldukları, ortalama tecrübenin ise 22,5 yıl olduğu görülmektedir. Yöneticilik yapan veya yapmış olan 58 üyenin yöneticilik tecrübesi ortalaması 15 yıl olarak bulunmuştur. Genel Müdür veya CEO'luk yapmış kadın üye sayısı 33'tür. Çalışma kapsamına alınan kadın üyelerin 21'inin kendi şirketlerinin veya şirket ortaklıklarının olduğu belirlenmiştir. Üyelerin aynı anda birçok yönetim kurulu üyelikleri de olduğu belirlenmiş olup, 17 üyenin en az iki farklı şirkette yönetim kurulu üyeliğinin bulunduğu, 7 üyenin üç farklı şirkette yönetim kurulu üyeliğinin olduğu, 1 üyenin dört farklı şirkette yönetim kurulu üyeliği olduğu belirlenmiştir. Bunun yanı sıra kadın üyelerin dernek, vakıf, birlik gibi sivil toplum kuruluşlarının kurucu üyeliği veya yönetim kurulu üyelikleri de bulunmaktadır. 49 üyenin STK yönetim kurulu üyelikleri 
bulunmaktadır. Buna göre önermenin sınanmasına yönelik gerçekleştirilen sınıflamalar çerçevesinde sosyal ağ analizinden elde edilen bulgulara bakılarak analizlere öncelikle sosyal ağ düzeneğinin büyüklüğü ve ilişki yoğunluğu testi ile başlanır. Buna göre Tablo 2 'de ağ ilişkilerine ait temel tanımlamalar gösterilmektedir.

Tablo 2. A ̆g Düzeneğine İlişkin Temel Tanımlamalar

\begin{tabular}{|c|c|}
\hline \multicolumn{2}{|l|}{ Sosyal Ă̆ Düzeneğinin Temel Bilgileri } \\
\hline A ̆g Bağlantısı Sayısı & 675 \\
\hline Yoğunluk & 0.0178 \\
\hline Ortak İlişkiler & 13 \\
\hline A ̌̆ Elemanlarının Sayısı & 490 \\
\hline A ̆g Matrisinin Boyutu & $490 \times 490$ \\
\hline Toplam Bağımsız Kadın Üye Sayısı & 70 \\
\hline
\end{tabular}

Çalışmanın önermesi kadınların kariyerlerinde yükselmelerini sağlayan biçimsel olmayan ağ ilişkilerinin önemine atıfta bulunmaktadır. Kadınlar için biçimsel olmayan ağların daha fazla önemi olduğu düşünülmektedir. Çünkü kadınlar erkeklere göre bu tür ağları kurmakta daha başarılıdır. Fakat biçimsel olmayan ağların iş odaklı yararlar sağlayacağını göz ardı etmektedirler. Bunun nedeni kadınların erkeklerin hâkimiyetindeki profesyonel iş odaklı biçimsel ağlara girmelerinin zorluğu, arkadaşlık ve sosyal destek olarak görüp kurdukları biçimsel olmayan ağların öneminin ise yeterince farkında olmamaları ve iş yaşamında da bu nedenle daima geri planda kalmalarıdır. Van Emmerik ve diğerlerinin (2006) ve Bourdil ve Géraudel'un (2016) belirlemiş oldukları biçimsel ve biçimsel olmayan ağ sınıflaması kullanılmış olup, ikincil verilerden edinilmiş ilişkilerin biçimsel ve biçimsel olmayan ağ ilişsileri olarak ayrımında ilişkinin sosyal veya ticari içerikli olup olmadığına odaklanılmıştır. Tablo 3'te biçimsel ağ ilişkilerinin ağırlıklandırma kıstaslarına göre oluşturulmuş ağ matrisinden ortaya çıkan kadın üyelere ait derece merkeziliği oranları sunulmaktadır.

Tablo 3. En Fazla Biçimsel Olmayan A ̆̆ İlişkilerine Sahip Kadınların Sıralaması

\begin{tabular}{|c|c|c|}
\hline Üye Kodu & Derece & Pay (\%) \\
\hline X54 & 85.00 & 16,00 \\
\hline X56 & 80.00 & 16,00 \\
\hline $\mathrm{X} 46$ & 80.00 & 16,00 \\
\hline $\mathrm{X} 28$ & 75.00 & 14,60 \\
\hline $\mathrm{X} 47$ & 70.00 & 13,40 \\
\hline $\mathrm{X} 14$ & 65.00 & 12,20 \\
\hline X29 & 60.00 & 11,00 \\
\hline X69 & 60.00 & 11,00 \\
\hline X18 & 58.00 & 10,00 \\
\hline A $\breve{\mathbf{g}}$ Ort. & \multicolumn{2}{|c|}{65.00} \\
\hline A $\breve{\mathbf{g}}$ Min. & \multicolumn{2}{|c|}{20.00} \\
\hline 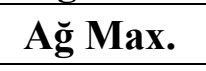 & \multicolumn{2}{|c|}{85.00} \\
\hline
\end{tabular}

Tablo 3'e göre sirasiyla X54, X56, X46, X28, X47, X14, X29, X69 ve X18 kodlu üyelerin biçimsel olmayan ağ ilişkileri en fazla olan üyeler olduğu görülmüştür. $\mathrm{Bu}$ 
kadınların biçimsel olmayan grupların içerisinde yer alma eğilimlerinin fazla olduğu

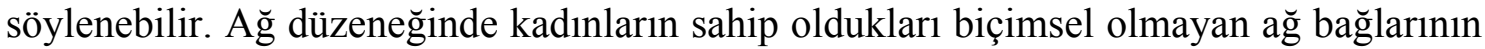
oranının fazla olduğu ve bu bağlamda kadınların biçimsel olmayan ağ üyeliklerinin kariyerlerinde yükselmelerine neden olduğu söylenebilir. $\mathrm{Bu}$ nedenle çalışmanın önermesi doğrulanmıştır.

\section{Sonuç ve Öneriler}

Son yıllarda yapılan araştırmalarda kadınların insan sermayelerinin çok yüksek düzeyde olmasının onları üst düzey yönetim kadrolarına taşımada tek başına yeterli olmadığ 1 vurgusu üzerinde durulmaktadır. A ̆g ilişkileri kurma ve ağların içine girme profesyonelleşme için önemli bir yöntemdir ve kadınların kariyer gelişimlerinin her bir aşamasında ağ ilişkilerinin önemi daha da artmaktadır (Forret ve Dougherty, 2001). Kurul içi üyelerin görüş ve nitelik benzerlikleri (homofili) kadınların kurula girmelerini engelleyen diğer bir unsurdur (Ibarra, 1992, 1997), ve kadınların ev ve çocuk bakım işleri yüzünden kurula girmeleri daha da zor olmaktadır (Forret ve Dougherty, 2001). Kadınların kendilerine benzeyen kişilerle özellikle de toplumsal baskı ve kalıp yargılar nedeniyle sadece kadınlarla ağlar kurma eğilimlerinin fazla olması kariyer gelişimleri için olumsuz değerlendirilmektedir. Kariyerinde üst düzey kademeleri hedefleyen kadınların bunu başarmaları için günümüz şartlarında en önemli stratejinin fayda ve güç kazandıracak sosyal ağlara kabul edilmek ve sosyal ağ ilişkilerinde iş odaklı ilişki ve bağlara odaklanmak olduğu söylenebilir. Kuramsal nitelikteki bu çalışma ile örgütlerin belirsizliği ve meşruiyet kaybı tehlikesini azaltmak gibi öncelikli görevlerine ve değişim halindeki koşulları yerine getirme zorunluluklarının önemi göz önüne alınarak bağımsız kadın yönetim kurulu üyelerinin kurullara girmeleri ve statülerini uzun süre korumak için nasıl davranmaları gerektiği ve en etkili eylemleri gerçekleştirmek zorunda olmaları nedeniyle sosyal sermaye düzeylerinin ve sosyal ağ ilişkilerinin çok önemli olduğunu gözler önüne sermektedir. Sosyal sermaye kuramının ve sosyal ağ ilişkileri özelliklerinin birlikte ayrıntılı olarak incelendiği bu çalışmada kuramsal bir çerçeve içinde araştırmanın önermesi oluşturulmuştur. Önermenin doğrulanması aşamasında kadınların iş yaşamında yükselmelerinde ve yönetim kurulu üyeliği gibi üst düzey görevlere seçilmelerinde sahip oldukları ve olmaya çalıştıkları ağ ilişkilerinin biçimsel ve biçimsel olmayan ilişki sınıflandırması altında incelenmesi sonucunda hangi tür bağlara sahip olmanın onlara daha fazla fayda sağlayacağı incelenmiştir. Kadınların iş yaşamında yükselme veya kariyerlerinde ilerlemeleri erkeklerin hâkimiyetinde olan, iş yaşamında yarar sağlayan biçimsel ağlar kurmalarına veya bu ağlara girmelerine engel olunduğu için hep geri planda kalmıştır. Kadınların herhangi bir müdahale ve destek olmadan önemli ağ ilişkileri kuramayacakları ve de bu ağların bir üyesi olmayacakları gerçekliği nedeniyle biçimsel olmayan ağ ilişkilerine sahip olan kadınların bu dezavantajı avantaja çevirmeleri tavsiye edilmektedir. Kadınların zorunluluklar ve kısıtlamalardan nedeniyle erkeklerin baskınlığında olan biçimsel ağlara girememeleri resmi ağların sağladığı kariyer avantajlarına ulaşamamalarına neden olmaktadır. Kadınların kariyer ilerlemelerini kolaylaştırmak için sahip oldukları bağlardan en yüksek faydayı sağlama yoluna gitmeleri yararlı olacaktır. Bu bağlamda ne kadar fazla sayıda biçimsel olmayan bağlar geliştirilirse o kadar iş odaklı faydaya sahip olunacağı söylenebilir. Biçimsel olmayan ağ ilişkileri en fazla olan üyelerin sirasıyla X54, X56, X46, X28, X47, X14, X29, X69 ve X18 kodlu üyelerin ağ ilişkilerinin fazla olduğu görülmüştür. $\mathrm{Bu}$ kadınların sosyal sermaye geliştirmelerinde sosyal ve profesyonel 
kulüp üyeliklerinden oluşan biçimsel olmayan ağ ilişkilerine ağırlık vermelerinin ve yeni bağlantı ve üyelik oluşturmaya daha fazla zaman harcamalarının etkili olduğu gözlenmiştir. A $\breve{g}$ düzeneğinde kadınların sahip oldukları biçimsel olmayan ağ bağlarının oranının fazla olduğu ve bu bağlamda kadınların biçimsel olmayan ağ üyeliklerinin kariyerlerinde yükselmelerine neden olduğu söylenebilir. Kadınların biçimsel olmayan ağ ilişkilerinin fazla olmasının üst düzey görevlere yükselmelerine sağlayacağ1 yönündeki önerme doğrulanmıştır.

Türkiye'de kadınların sosyal sermaye oluşturma eğilimleri sonucunda ortaya çıkan ağ düzeneklerinin belirlenmesi toplumun kültürel özelliklerinin benimsenmesi kapsamında ele alınması önerilebilir. Kadınların kariyer gelişimlerinde sosyal sermayelerinin önemi bu çalışmada ortaya çıkmaktadır. Kadının sosyal yaşamlarında annelik rolünün olması, kadınlık cinsiyetine ait kalıp yargıların baskısında çekici veya cinsel obje olarak görülmesi onları sadece diğer kadınlarla iletişim kurmaya itmektedir. Aile baskısı ve kültürel kısıtlar profesyonel yönetici konumundaki kadınların kariyer gelişimlerinde belirgin olarak fark edilmektedir. Dünya genelinde kadın yöneticilerin az olması ve kadın yönetim kurulu üyesi olmanın engellenmesi cam tavan engelleri olarak yazında yer bulmuş ve çok sayıda araştırmaya konu olmuştur. Gelecekte yapılacak çalışmalarda sınıflandırma kriterlerinin konu hakkında çok fazla bilgisi ve yetkinliği olan hakemler tarafindan yeniden değerlendirilmesi ve farklı yöntemlerle konunun daha da derinlere inerek güncelliğinin artırılması sağlanabilir. Bu kısıtlara rağmen bu çalışmanın ulusal ve uluslararası yazında hem konu olarak hem de kullanılan yöntem ve elde edilen bulgular bakımından benzerinin olmaması nedeniyle gelecekte gerçekleştirilecek benzer araştırmalara önemli katkılar sağlayacağı ve bu konuda çalışan araştırmacılara yeni araştırma alanları açacağı düşünülmektedir.

\section{Araştırmanın Güçlü Yönleri ve Kısıtları}

$\mathrm{Bu}$ çalışma kuramsal temelde dikkatle ve itinayla hazırlanmış olmakla beraber konuyla ilgili olan ve olabilecek tüm kaynaklar incelenmiş ve en güncel kaynaklar ve kuramsal çalışmalara yer verilmiştir. Kadınların sosyal sermaye ve sosyal ağ ilişkileri özellikleri ile ilgili geniş bir yazın taraması yapılmış ve çalışma kapsamındaki tüm hususların kuramsal temellerine vurgu yapılmaya çalışılmıştır. Kadınların sosyal sermayelerinin kariyer ilerlemeleri için gerekli ve zorunlu bir ihtiyaç olması nedeniyle bu konunun araştırılması faydalı olacağı değerlendirilmiştir. Kadınların üst düzey yönetsel kademelere ulaşmalarında sosyal sermaye edinim biçimlerinin ortaya çıkartılması için bu araştırmaya hangi grup kadınların dâhil edileceği önemli bir unsurdur. Kadınların seçiminde yazına en fazla katkıyı sağlayacak kapsam olarak üst düzey yönetici konumundaki kadınların seçilmesi ve çalışma çerçevesinde toplanan ikincil veriler neticesinde analizlerin yapılması uygun görülmüş̧ür. Yönetim Kurulu üyeliği gibi gelinmesi bir kadın için çok zor olan görevlere ulaşmış kadınlardan elde edilecek verilerin konuya açıklık kazandıracağı düşünülmüştür. Bu çalışma sürecinde, kadınların sosyal sermaye ve sosyal ağ ilişkileri özelliklerine dair örgüt kuramları bakış açısıyla yapılmış bir çalışmaya rastlanmamış olunması çalışmanın bu anlamda yazına önemli katkı sağlayacağını göstermektedir. Özellikle kadınların a ̆̆ ilişkilerinin faydalarına dair şimdiye kadar cinsiyete dayalı bir çalışma yapılmamıştır.

Araştırmanın veri toplama ve analiz sürecinde de bazı sınırlılıkları bulunmaktadır. Araştırma için toplanan verinin büyüklügüne bağlı olarak, yüz yüze görüşme veya anket yöntemi ile veri toplamak zaman alıcı, uygulanması zor bir yöntem olması nedeniyle 
ikincil veri kaynaklarından yararlanılmıştır. Ayrıca, matrislerin oluşturulması sürecinde, belirli bir büyüklüğü aşmaması için bazı ilişkiler araştırma kapsamı dışında bırakılmıştır. Diğger bir kısıt ise çalışma kapsamına alınan kadın üyelerin ilişki ve sosyal temaslarına ilişkin ağırlıklandırılmış matris için oluşturulan sınıflamanın yazından derlendiği şekliyle kullanılması tek başına yeterli olamayacağı ve bu durumun nedeni olarak bu konularda yeterli çalışmanın yapılmamış olması gösterilebilir.

\section{Kaynakça}

Aaltio, I., ve Huang, J. H. (2007). "Women managers' careers in information technology in China: High flyers with emotional costs", Journal of Organizational Change Management, 20(2), 227-244.

Anderson, A.R., ve Jack, S. L. (2002). "The articulation of social capital in entrepreneurial networks: A glue or lubricant?", Entrepreneurship and Regional Development, 14, 193-210.

Barr, A. (1998). "Enterprise Performance and the Functional Diversity of Social Capital", Working Paper Series, 98-1, Institute of Economics and Statistics, University of Oxford.

Bartol, K. M. (1978). “The sex structure of organizations: A search for possible causes", Academy of Management Review, 5, 805-81.

Bilimoria, D. (2000). "Building the business case for women corporate directors", In: Burke, R. and Mattis, M. (eds.) Women on Corporate Boards of Directors: International Challenges and Opportunities, 25-40. Kluwer, Dordrecht.

Borgatti, S. P., ve Foster, P.C. (2003). "The network paradigm in organizational research: A review and typology", Journal of Management, 29: 991-1013.

Bourdieu, P. (1983). "Ökonomisches Kapital, Kulturelles Kapital, Soziales Kapital”, Hrsg: Kreckel, Reinhard, Soziale Ungleichheit, Soziale Welt, Sonderband 2. Göttingen, s. 183-198.

Bourdil, M., ve Géraudel, M. (2016). "What are the interpersonal antecedents of women's network satisfaction? A study conducted with French women entrepreneurs", Gender in Management: An International Journal, 31 (4):266280

Brass, D. J. (1985). “Men's and Women's Networks: A Study of Interaction Patterns and Influence in an Organization", Academy of Management Journal, 28(2):327-43.

Burke, R. J. (2000). "Company size, board size, and the numbers of women corporate directors", In Burke, R. and Mattis, M. (Eds), Women on Corporate Boards of Directors: International Challenges and Opportunities, Kluwer, Dordrecht, s. 118-125.

Burke, R. J., Rothstein, M. G., ve Bristor, J. M. (1995). "Interpersonal networks of managerial and professional women", Women in Management Review, 10(1): 21. 
Burt, R. (1980). "Cultural Myths and supports for rape", Journal of Personality and Social Psychology, 38 (2): 217-230.

Burt, R. (1992). "Structural holes: The social structure of competition", Cambridge, MA: Harvard University Press.

Burt, R. (1997). “The Contingent value of social capital”, Administrative Science Quarterly. 42:339-365.

Burt, R. (1998). “The gender of social capital”, Rationality and Society, 10(1):5-46.

Burt, R. (2005). "Brokerage and closure: An introduction to social capital", Oxford: Oxford University Press

Cannings, K. ve Montmarquette, C. (1991). "Managerial momentum: a simultaneous model of the career progress of male and female managers", Industrial \& Labor Relations Review, 44(2): 212-28.

Coleman, J. (1988). "Social capital in the creation of human capital", American Journal of Sociology Supplement, 94:93-120.

Coleman, M. (2010). "Women-only (homophilous) networks supporting women leaders in education", Journal of Educational Administration, 48(6):769-781

Cromie, S. (1992). "Networking by female business owners in Northern Ireland", Journal of Business Venturing, 7(3):237-251

Davidsson, P. ve Honig, B. (2003). "The role of social and human capital among nascent entrepreneurs", Journal of Business Venturing 18(3):301-331.

Davidson, M. J., ve Burke, R. J. (2000). "Women in management: current research", vol 2. London: Sage Publications Ltd.

Degenne, A. ve. Forse, M. (1999). “Introducing Social Networks”, London: Sage.

Dulworth, M. (2008). "The Connect Effect: Building Strong Personal, Professional, and Virtual Networks", San Fransisco: Berrett-Koehler Publishers.

Durbin, S. (2011). "Creating Knowledge through Networks: a Gender Perspective, Gender", Work and Organization. 18(1).

Fletcher, C., Boden, R., Kent, J. ve Tinson, J. (2007). "Performing women: the gendered dimensions of the UK new research economy", Gender Work and Organization, 14(5): 434-53.

Forret, N. L. ve Dougherty, T. W. 2001. Correlates of networking behaviour for managerial and professional employees, Group and Organisation Management, $26(3): 283-311$.

Friedman, R., Kane, M. ve Cornfield, D.B. (1998). "Social support and career optimism: examining the effectiveness of network groups among black managers", Human Relations, 51 (9):1155-77.

Fukuyama, F. (2000). “Güven (Sosyal Erdemler ve Refahın Yaratılmas1)”, 2.bask1, İstanbul, Türkiye İş Bankası Yayınları.

Granovetter, M. (1973). "Strength of Weak Ties", American Journal of Sociology, 78: 1360-1380. 
Granovetter, M. (1983). "The strength of weak ties: A network theory revisited", Sociological Theory, 1: 201-233.

Granovetter, M. (1985). "Economic Action and Social Structure: The Problem of Embeddedness", American Journal of Sociology, 91(3): 481-510.

Hanneman, R. A. (2001).“Introduction to social network methods", Riverside: University of California Riverside.

Hanneman, R.A. ve Riddle, M. (2005). "Introduction to social network methods". Riverside, CA: University of California, Riverside (published in digital form at http://faculty.ucr.edu/ hanneman/ )

Hansen, M., Ibarra, H. ve Peyer, U. (2010). "The best-performing CEOs in the World", Harvard Business Review, 88:104-113.

Hawarden, R. J. (2010). "Women on Boards of Directors: The Origin and Structure of Gendered Small-World and Scale-Free Director Glass Networks", Doctoral Thesis, Massey University,

Heilman, M. E. ve Haynes, M. C. (2005). "Attributional rationalization of women's success in mixed-sex teams: No credit where credit is due", Journal of Applied Psychology, 90 (3):905- 916.

Hodigere, R.,ve Bilimoria, D. (2015). "Human Capital and Professional Network Effects on Women's Odds of Corporate Board Directorships", Gender in Management: An International Journal, 30 (7):523-550

Ibarra, H. (1992). "Homophily and Differential Returns: Sex Differences in Network Structure and Access in an Advertising Firm", Administrative Science Quarterly, 37(3):422-47.

Ibarra, H. (1993). "Personal Networks of Women and Minorities in Management: A Conceptual Framework". Academy of Management Review, 18(1):56-87.

Ibarra, H. (1997). "Paving an alternative route: Gender differences in managerial networks", Social Psychology Quarterly, 60(1):91-102.

Inkpen, A. C., ve Tsang, E. W. (2005). "Social Capital, Networks, and Knowledge Transfer", Academy of Management Review, 1(30):146-165.

Kanter, R. (1977). "Men and Women of the Corporation”, Basic Books, New York.

Lankau, M. J., ve Scandura, T. A. (2002). "An investigation of personal learning in mentoring relationships: Content, antecedents, and consequences", Academy of Management Journal, 45(4):779-790.

Leung, K. Bhagat, R.S. Buchan, N.R. Erez, M. ve Gibson, C.B. (2005). "Culture and international business: recent advances and their implications for future research”, Journal of International Business Studies, 36(4):357-378.

Lin, N. (2001). "Social capital: A theory of social structure and action", Cambridge, MA: Cambridge University Press.

Linehan, M., ve Scullion, H. (2008). "The development of female global managers: the role of mentoring and networking", Journal of business ethics, 83(1):29-40. 
Livesey, R., ve Rotheroe, N, (2007). “Women's business networks, do they contribute to sustainibility by facilitating bonding and bridging social capital ties, increasing confidence and encouraging creativity and sharing of good ideas?", Journal of Finance and Management, Special edition, Social enterprise.

Loscocco, Karyn A., Shannon M. Monnat, Gwen Moore, ve Kirsten B. Lauber, (2009). "Enterprising Women: A Comparison of Women's and Men's Small Business Networks." Gender and Society, 23(3):388-411.

Maxwell, G. A. and Broadbridge, A. (2014). "Generation Y graduates and career transition: Perspectives by gender”, European Management Journal,32, pp.547553.

McGuire, G. M. (2000). "Gender, race, ethnicity, and networks: The factors affecting the status of employees' network members", Work and Occupations, 27:500523.

Nahapiet, J., ve Ghoshal, S. (1998). "Social capital, intellectualcapital, and the organizational advantage", The Academy of Management Review, 23: 242-266.

Narayan, D. (1999). "Bonds and Bridges: Social Capital and Poverty", Policy Research Working Paper No. 2167 (Washington, DC: The World Bank).

Perriton, L. (2006). “Does woman network $1 / 4$ career progression?”, Leadership, 2(1):10113.

Pini, B., Brown, K. ve Ryan, C. (2004). "Women-only networks as a strategy for change? A case study from local government", Women in Management Review, 19(6):286-92.

Podolny, J. M., ve Baron, J. N. (1997). "Resources and relationships: Social networks and mobility in the workplace", American sociological review, 673-693.

Powell, G. N. (1993). "Women and Men in Management", 2. Basım, Sage Publications, Londra, s. 85-86.

Powell, G.N. (2000). "The glass ceiling: explaining the good and bad news", in Davidson, M.J. and Burke, R. (Eds), Women in Management: Current Research Issues, Vol. II, Sage, London, s. 236-49.

Putnam R. D. (1995). "Bowling alone: America's declining social capital”, Journal of Democracy, 6(1):65-78.

Ragins, B. R., ve E. Sundstrom., (1989). "Gender and Power in Organizations: A Longitudinal Perspective”, Psychological Bulletin, 105(1):51-88.

Rangan, S. (2000). "The problem of search and deliberation in economic action: when social networks really matter", Academy of Management Review, 813-836.

Rindfleish, J. M., ve Sheridan, A. J. (2003). "No Change From Within: Senior women managers' response to gendered organizational structures"

Sheridan, A. (2002). "What you know and who you know: "successful" women's experiences of accessing board positions", Career Development International, 7(4):203-210 
Shortland, S. (2011). "Networking: a valuable career intervention for women expatriates?", Career Development International, 16 (3): 271- 292

Sözen, H.C. (2007). "Bağlam kapsamında örgütler arası ağ düzenekleri: dayanıklı ev aletleri sektörü örneği”, Başkent Üniversitesi, Yönetim Organizasyon Doktora Tezi.

Sözen, H.C. ve Sağsan, M. (2009). "Social Networks Versus Technical Networks: How Different Social Interaction Patterns Effect Information System Utilization in the Organizations?", Journal of US-China Public Administration, 65-72.

Sözen H.C. (2012). "Social networks and power in organizations: A research on the roles and positions of the junior level secretaries in an organizational network", Personnel Review, 41(4):487-512.

Timberlake, S. (2005). "Social Capital and Gender in the Workplace", The Journal of Management Development, 24(1):34-44.

Van Emmerik, I.J.H., Euwema, M.C., Geschiere, M. ve Schouten, M.F.A.G. (2006), "Networking your way through the organisation: gender differences in the relationship between network participation and career satisfaction", Women in Management Review, 21(1):54-66.

Wang, J. (2009). Networking in the workplace: Implications for women's career development, New Directions for Adult and Continuing Education, 122: 33-42.

Waring, M. (1988). "Counting for nothing: What men value and what women are worth", New Zealand: Allen \& Unwin/Port Nicholson Press.

Wasserman, S., ve Faust, K. (1994). "Social Network Analysis: Methods and Applications", Cambridge: Cambridge University Press

Woolcock, M., ve Narayan, D. (2000). "Social Capital: Implications for Development Theory, Research, and Policy", World Bank Research Observer, 15(2):225250. 


\section{The Role of Formal and Informal Social Networks in Social Capital Acquisition: An Investigation on Women Board Directors}

\author{
Hale ALAN \\ Turkish Patent and Trademark Office \\ 06330 Yenimahalle \\ Ankara, Turkey \\ haletpe@gmail.com
}

\author{
H. Cenk SÖZEN \\ Başkent University \\ Faculty of Economics and Administrative \\ Sciences, Ankara, Turkey \\ csozen@baskent.edu.tr
}

\section{Extensive Summary}

\section{Introduction}

The social capital theory has been described in many ways by different disciplines and different researchers. In this study, it was aimed to reveal the formal and informal social networks of social capital in terms of relations and connections. Social capital is defined as the internal social and cultural coherence of society, groups and individuals the norms and values that govern interactions among people and the institutions in which they are embedded. There are network relationships and relationship ties at various levels and characteristics within the individual and within a social network. Although social capital and social network theories have given women a comprehensive view of the process of coming to senior management positions, the impact of social capital and social networking on women's career progression is one of the subjects ignored by researchers (Hawarden, 2010). Social networking features are important for women to reach higher levels as a hierarchy. In addition to the researches that reveal gender differences in social networking relationships, few studies have shown that there is no difference between male and female networks. It was observed that in these studies women were more likely to focus on informal network relationships of social and professional club memberships in social capital creation and to spend more time creating new connections and memberships (Cromie, 1992). The first aim of networking activities is to acquire social capital. Networking takes the form of formal and informal relationships involving professional associations, looking for high-level tasks that are becoming more prominent, participating in social activities, and establishing professional communications (Forret and Dougherty, 2004).

\section{Formal and Informal Networks}

The distinction between social networks as formal and informal networks is the most widespread categorization that social networks can be developed both within organizations and outside organizations (Bourdil and Géraudel, 2016; Livesey and Rotheroe, 2007). According to Van-Emmerik et al. (2006), social work meetings held several times a year in an organization are also examples of formal network relations. Because their history is clear, the participants are defined and the purpose of the meeting is definite. Women's informal networks are scarce because they can not afford leisure time for home and child care (Kanter, 1977; Hansen et al, 2010). Women who are constantly behind the scenes to get involved in important networks and benefit from networks are trying to complete these shortcomings by connecting them with their male 
colleagues. Van Emmerik et al. (2006) calculated the formal formations in the networks to identify formal network memberships. The informal networks are provided information resources by heterogeneous groups formation. It is stated that men have the networks comprised of memberships of voluntary associations and social life with various social institutions (Davidsson and Honig, 2003). Because of the difficulties and obstacles women are exposed to, the inability to enter formal business networks dominated by men leads to their inability to reach the career advantages of formal networks (Coleman, 2010). Women who are able to enter formal networks can be examined under formal and non-formal relationship classifications of network relations they have or trying to have in their career development and when they are elected to senior management levels such as board directors. It is estimated that the greater the number of informal networks that are included relationships and contacts developed by women, the more work and career-oriented benefits they will have. So, the research proposal is as follow;

Proposition: Women are expected to have a lot of informal relations and contacts in their social network for their career development and to have access to senior management level.

\section{Methodology}

With this study, the independent women's board of directors of the organizations that are traded in BIST (Borsa İstanbul A.Ş.) have been researched. A total of 588 organizations were surveyed and social capital and networks of 70 independent women board directors were researched. Social network analysis is a way of visualizing the connections between people and the properties of those links. The weighted matrix method is used for social network analysis. The network relations of independent women board directors were obtained from secondary data sources. Archive data, resumes, newspaper news, personal web sites, personal information, schools, company and experience, family ties, friends, volunteer activities were investigated. UCINET version 6.0 (Borgatti et al., 2002) was used for network analysis. It is evaluated that every independent women board member included in the survey has a name in the country and is thought to be working on the boards of established companies, and that their awareness will be high and can be reached through a lot of information or secondary data sources. In this study, the network classification used by Van Emmerik et al. (2006) and the formal and unformal network classification generated by Bourdil and Géraudel (2016) are used. The degree centrality values and the averages (UCINETNetwork $>$ Centrality $>$ Degree centrality) of the matrix of the formal and informal networks created for testing the proposal are calculated.

\section{Conclusions}

This study is revealed that the progress of the social capital acquisition via social network relations. It hopes to contribute to the international debate on the role and importance of informal social networks as an element of career improvement. With this theoretical work, it is essential that independent women board directors should enter the boards and act to maintain their statues for a long time, taking into account the priority tasks of organizations such as reducing the risk of uncertainty and loss of legitimacy and the necessity of fulfilling the conditions of change. This study is revealed that the social capital levels and social network relations are very important. As a result of examining women relationships in formal and informal classification of relationships 
they have and are trying to have in their ascendancy in the workplace and in their election to senior positions such as membership in the board of directors, it has been examined what kind of ties will have more benefits for them. In this context, it can be said that the more numerous informal links are developed; the more job-oriented benefits will be obtained. It has been observed that the network relationships of the members with the most informal network associations are more than those of members $\mathrm{X} 54, \mathrm{X} 56, \mathrm{X} 46, \mathrm{X} 28, \mathrm{X} 47, \mathrm{X} 14, \mathrm{X} 29, \mathrm{X} 69$ and X18 respectively. The proposition that women will lead to higher levels of higher-level tasks, which is too much of informal network relations, has been confirmed. 